Sveučilište Josipa Jurja Strossmayera u Osijeku bkuna@ffos.hr

Damira Nujić

Sveučilište Josipa Jurja Strossmayera u Osijeku damira.nujic@gmail.com

\title{
O rodno osjetljivom jeziku
}

Abstract: Kuna Branko, Nujić Damira, O rodno osjetljivom jeziku (On Gender-Sensitive Language). "Poznańskie Studia Slawistyczne" 9. Poznań 2015. Publishing House of the Poznań Society for the Advancement of the Arts and Sciences, pp. 303-318. ISSN 2084-3011.

This paper focuses on changes in Croatian language that either have happened or are possible to happen in order that male dominance in language and gender inequality are reduced. The research concentrates on the use of gender-sensitive language for job titles and occupations of female persons. The study demonstrates the lack of stability in the use of feminine forms, as it has not been integrated into the Croatian language practice yet.

KEYwORDs: gender; sexism; naming; gender-specific formation of nouns; political correctness; Croatian

\section{Uvod}

Temeljna je uloga jezika razmjena kodiranih poruka između govornika i slušatelja u svrhu prijenosa obavijesti, a jezik je ujedno odraz društva i posljedica njegova hijerarhijskog ustroja te relacija koje vladaju između sudionika u komunikaciji. No ta je uzajamnost jezika i društva dvosmjerna jer se mreža relacija među članovima društvene zajednice utvrđuje (i potvrđuje) jezičnom djelatnošću (Škiljan 2000: 13)1. Iz prethodnoga bi se moglo poopćiti da promjena položaja bilo koje društvene skupine nužno mora ostaviti traga i u jeziku jer se naša stvarnost oblikuje jezikom. S obzirom na to da ima nedvojbenu moć utjecaja na društvo, jezik je prepoznat i kao ključno oruđe borbe za rodnu ravnopravnost.

${ }^{1}$ Dubravko Škiljan govori o „komunikacijskoj” djelatnosti kao nadređenom pojmu u sklopu koje jezična djelatnost ima najvažniju ulogu. 
I dok je jezik s jedne strane dio sustava represije žena, s druge strane može postati oružje u borbi protiv podređenosti žena. U jezikoslovlju postoji više pristupa koji na različite načine žele ukazati na položaj žene u jeziku, ali se svi slažu da je njezin položaj podređen u odnosu na muškarca. Erving Goffman tako smatra da rodne uloge nisu primarno biološki uvjetovane već su one rezultat višestoljetne društvene organizacije zamišljene kao „scena” koja ne omogućuje izražavanje rodnih razlika, već ona te razlike proizvodi (Goffman 1977: 310-331). Za „nepovoljan i uvredljiv tretman žena u jeziku na osnovi spola" (Bratanić 2005: 37-38) ili diskriminaciju na temelju rodne pripadnosti ustalio se naziv seksizam. Promičući seksističke oblike, jezikom se učvršćuje hijerarhijska podjela na rodove te se tako onemogućuje promjena te podjele. „Sexism is a system in which women and men are not simply different, but unequal (...) Sexism in language is one manifestation of the system, and it works to the disadvantage of women, not men" (Cameron 1992: 100). Prevlast androcentričnosti u jeziku, posebice na gramatičkom planu, iz hrvatskog jezika teško je ukloniti. Tako Mislava Bertoša spominje oslovljavanje ženskih osoba iz poštovanja, npr. 'Vi ste pogriješili'. Zamjenica Vi veže množinski muški oblik glagola „tako da zapravo obraćanje ženama iz poštovanja u (ili možda, prema) njihovu rodu postaje jezično nemoguće - ženi se je moguće obratiti samo u obliku muškog roda" (Bertoša 2001: 73). Međutim, takve je oblike nemoguće promijeniti zbog sročnosti s muškim glagolskim oblikom - to je pitanje gramatike. Ali i kada bi se promijenili, to samo po sebi ne bi promijenilo položaj žene u društvu. Androcentričnost se potiče i dalje ponajprije imenovanjem kojim muškarac dokazuje svoju sadašnju, ali osigurava i buduću dominaciju u društvu te tako konstruira društvo i kontrolu. Julia Penelope stoga zaključuje: „Men control naming, an important aspect of any language" (Penelope 1990: 47).

Uz muško oblikovanje jezika, vidljivo po neutralnosti i dominantnosti muškoga roda, veže se teorija Shirley i Edwina Ardenera koja se opisuje kao teorija dominantnih i pritajenih. Oslanjajući se na determinizam, odnosno jezično kreiranje zbilje, autori spomenute teorije ističu da, iako svaka skupina stvara vlastite ideje o stvarnosti, nema svaka jednake mogućnosti za njihovo iskazivanje, odnosno nemaju jednak pristup ,to the mode of specification" (Cameron 1992: 141), lingvističkom sustavu koji oblikuje stvarnost određene kulture. Predstavnice ušutkanih i pritajenih 
skupina jesu žene koje, da bi mogle sudjelovati u društvu, moraju vlastitu stvarnost izražavati muškim kodom. Seksizam je pozadinsko pravilo brojnih jezika i utječe na percepciju roda u određenoj kulturi, a dobrim dijelom može ga se dovesti u vezu sa stereotipima o ženama. Iako muški stereotipi podržavaju nedolična stajališta o ženama, oni su nastali uglavnom kao posljedica objektivnih odnosa između rodova tijekom povijesti u kojoj je bila zajamčena supremacija muškaraca nad ženama. Civilizacijski napredak i promjena svijesti usporedno trebaju podrazumijevati uklanjanje stereotipa kao okamenjenih jezičnih klišeja. Na putu stvaranja novih, ravnopravnijih formi u jeziku i kulturi nastaje paradoks o kojem Deborah Cameron kaže sljedeće: „Are woman unable to effect language because they lack power - in which case they cannot hope to encode their own meanings without first changing their status - or is it the lack of linguistic resources that renders them powerless?" (Cameron 1992: 151).

Svrha je ovoga rada propitati mijene u jeziku koje su u hrvatskom društvu nastale kao rezultat novih zakonskih propisa ${ }^{2}$, pojačanog zanimanja „ženskih skupina” za ravnopravnost i potvrđivanje žene u jeziku u posljednjih dvadesetak godina, posebice u najvidljivijem i najprozirnijem dijelu jezičnoga sustava - leksiku - koji najlakše podliježe promjenama te se na leksičkoj razini lako utiskuju društvene mijene. Zbog derivacijskih mogućnosti hrvatskoga jezika mocijska tvorba postaje aktivno i prepoznatljivo sredstvo u jačanju zastupljenosti rodno osjetljivog jezika u javnom jeziku, tu se prije svega misli na široki opseg tvorbe oblika kojima se imenuju zanimanja, zvanja i titule osoba ženskoga spola. Naravno, dosljedna mocijska tvorba nije uvijek moguća, a zapreke u njezinoj provedbi mogu nastati zbog različitih razloga.

U nastavku se propituje rječničko i normativno određenje rodno osjetljivih oblika te se raspravlja i o pragmatici mocijskih parova, njihovom nadopunjavanju dodatnim rodnim oznakama u jednom dijelu javnog prostora - oglasima za posao. Još u samim začetcima pragmatičkih istraživanja ističe se složenost i suptilnost značenja te raznolikost komunikacijskih oblika. A za potpuno razumijevanje značenja od posebne je važnosti prepoznavanje

\footnotetext{
${ }^{2}$ Najvažniju ulogu u tome imaju prvi Zakon o ravnopravnosti spolova koji je na snazi od 14. srpnja 2003., a novi od 2008. Valja naglasiti da žene imaju pravo glasa na izborima još od 11. kolovoza 1945. (Hrvatska se tada nalazi u sklopu Jugoslavije), znatno prije negoli u mnogim drugim državama zapadne demokracije.
} 
govornikove namjere (Sperber, Wilson 2005: 450), kontekst i činjenica da se uvijek više prenese nego što se izgovori (Yule 1996: 3). Također, u radu se nastoji utvrdi koliko su u diskursu oglasa mocijski parnjaci samo ures „lošeg jezika” kojim se izriču predrasude i favorizira samo jedan rod, a što je protivno pojmu političke korektnosti.

\section{Imenovanje žene i leksikografska obradba}

Neobično je to što se i u jezikoslovnoj literaturi podržavaju stereotipi i seksistička uporaba jezika. U leksikografskim odredbama (opisima) natuknica u suvremenim hrvatskim rječnicima može se naći podosta takvih primjera na što se upozoravalo iz različite perspektive. Uzmimo za primjer imenicu 'čovjek'. Marija Znika (1994: 313-322) tvrdi da uz tu natuknicu u leksikografskoj obradbi nije u cijelosti točna oznaka 'm.', odnosno da je muškoga roda. Iako je to u suglasju s većinom prvih leksičkih značenja odrednica u hrvatskim jednojezičnicima u kojima se obično opisuje kao „muško čel̦ade” (RHISJ: 70) ili „odrastao, zreo muškarac” (RHJ: 147), ta se imenica rabi i generički u značenju 'bilo koje ljudsko biće' te bi se ono trebalo i bilježiti u rječnicima. Da nije tako, sljedeća rečenica ne bi bila prihvatljiva:

Shakira bi u cirkusu bila ‘čovjek od gume’ (24sata, 23.05.2013.).

Za strože razgraničenje roda i spola u rječnicima zalaže se Branka Tafra (2005) koja smatra da je prvoj kategoriji (rodu) mjesto uz natuknicu na lijevoj strani, a spol je dio leksičkoga značenja te treba biti sastavnim dijelom definicije natuknice na desnoj strani. Ipak, odbacuje posebno označivanje generičke uporabe riječi 'čovjek' jer bi se onda takva oznaka trebala navoditi uz sve nazive životinja u kojima je uvijek „neutraliziran spol”. Snježana Kordić primjer uporabe u izdvojenoj rečenici naziva „kvazi-nereferencijalnim" jer se u biti uvijek prikriveno referira na konkretnu osobu koja je polazište uopćavanja, ali se slaže kako je takva uporaba neutralna s obzirom na spol. Navođenjem idioma iz Anićeva rječnika autorica obrazlaže i kako su „biološka, fizička svojstva prepreka protezanju riječi čovjek i na ženski spol” (Kordić 2001: 473). Za oba spola mogu vrijediti 
idiomi koji upućuju na psihičke kvalitete: 'svoj čovjek; svjetski čovjek; duša od čovjeka', no ako su uključene fizičke oznake spola u pravilu se pojavljuju inačice idioma: 'pravi čovjek', ali i 'prava žena'.

U leksikografiji valja razlučiti jezičnu diskriminaciju od činjenica koje ne proistječu iz opisa, već ih on samo registrira: „To što augmentativ 'muškarčina' uvijek ima pozitivan, a 'ženetina' negativan predznak - leksička je datost”, tvrdi Maja Bratanić (2005: 39) u svom radu o „leksikografskoj” diskriminaciji i seksizmu u hrvatskim rječnicima. Autorica upozorava kako se neopravdano u jednojezičnicima zasebno ne opisuje u natuknici osobna zamjenica ONA, pri čemu se isključuje njezino značenje obrazloženjem kako je ono suvišno jer je u izravnoj tvorbenoj vezi s muškim parnjakom - zamjenicom ON. Dijelom je s tim u vezi i početak leksikografskih odrednica riječi koje imaju mocijske parnjake - (pristranom) androcentričnom formulom „onaj koji” umjesto neutralnog „osoba koja”. U Anićevu rječniku (1991) te u Šonjinu RHJ posebno se znakovitim čini neprikladan i nepovoljan opis ‘žene’ koji izdvaja više autorica (npr. Borić 2004; Bratanić 2005; Cesar, Gospočić, Ćorić, Ivanković Knežević, Obradović-Dragišić, Tomić-Koludrović 2005). Žena je predstavljena kao otklon od pozitivno određenog pojma muškarca: ,pod odrednicom muškarac nema niti jednog frazeološkog izraza, za ženu se navode javna žena - prostitutka, laka žena - lako osvojiva žena u predrasudi da ne bira partnera" (Borić 2004: 18). U priručniku Rodna perspektiva u politici i praksi autorice se također osvrću na dominantnu ulogu muškaraca u kulturi, posebice na dominaciju u jeziku kao refleksiji i posljedici patrijarhalne kulture: „Jezik, način razmišljanja i komuniciranja s drugima ostvaruje i utjelovljuje mušku dominaciju. Ono što je u jeziku muško općenito je osnovno, a ono što je žensko sporedno je i/ili neodobravano. Rječnik hrvatskog jezika kaže da je žena osoba po spolu suprotna muškarcu, a muškarca definira kao odraslu osobu muškog spola" (Cesar, Gospočić, Ćorić, Ivanković Knežević, Obradović-Dragišić, Tomić-Koludrović 2005: 26). Dakle, ženino je osnovno obilježje njezina suprotnost muškarcu, dok u definiciju muškarca žena nije uključena. ON je predstavljen cjelovitim identitetom, a njezin proizlazi iz njegova identiteta, a takvim prikazom unaprijed se njihov odnos određuje kao hijerarhijski.

Zanimljivo je kako i dvije spomenute autorice različito interpretiraju jedan te isti mocijski par. Tako Bratanić na primjeru natuknice ' ljubavnik $_{\mathrm{m}}$ ' ('ljubavnica') opisanog u RHJ s 1. značenjem: 'muškarac koji održava 
trajne ljubavne odnose sa ženom s kojom nije u braku' zaključuje kako je to nepotpuna i neprikladna definicija zato što se ne može protegnuti na drugi dio para 'ljubavnicu', ,jer osnovna komponenta značenja ovdje nije samo da je ta žena u vezi s čovjekom koji nije u braku, već i činjenica da je taj čovjek oženjen" (Bratanić 2005: 41). Robin Lakoff također se bavila odnosom navedenog mocijskog para kojemu u engleskom jeziku odgovaraju mocijski parnjaci master i mistress. Obje su riječi najprije označivale nečiju moć nad nekim, ali se s vremenom oblikovalo novo značenje. „master now generally refers to a man who acquired consummate ability in some field, normally non-sexual. But its feminine counterpart cannot be used in this way. It is practically restricted to its sexual sense of "paramour"” (Lakoff 1973: 63). Dok se muškarcima i dalje priznaje moć nad nekim, ženama je takva moć isključivo seksualno obojena.

Da leksem 'ljubavnica' ni u kom slučaju ne može biti izjednačen sa svojim muškim parnjakom, potvrdu navodi i Tafra dokazujući kako je gramatičko variranje roda predvidljivo, za razliku od semantičkoga. No tim je primjerom potvrdila seksističko određenje tog leksema. 'Ljubavnica' može označivati i mušku osobu, kao u sljedećem: „Situacija je viđena $\mathrm{u}$ jednom filmu u kojem poslovna žena seksualno iskorištava svoga kolegu da bi došla do većeg poslovnog uspjeha. Kad to postigne, odbacuje ga, a on, shvativši svoj položaj, kaže: Bio sam ti ljubavnica" (Tafra 2005: 95). Imaginarni lik, iako muškarac, samo je potvrdio na vlastitu primjeru uvriježene konotacije „leksičke datosti” 'ljubavnice' kao osobe koja je u vezi 'uvijek druga' i 'zamjenjiva', a da nikako ne može biti 'ljubavnik' jer je to i onaj „koji ima uspjeha u ljubavi” (RHJ: 558). U literaturi postoji čitav niz drugih primjera koji problematizira neprimjereno leksikografsko određenje pojedinih mocijskih parnjaka, tvorbenih i leksičkih, poput: 'mudrac/ mudrica; profesionalac/profesionalka; ljepotan/ljepotica; rastavljeni muškarac/raspuštenica; domaćin/domaćica; učenik/učenica' i dr. Svima im je zajedničko upozoravanje na diskriminacijski jezik usmjeren protiv žena koji uporište ima u društvenom shvaćanju koje treba mijenjati usporedno s jezičnim oblicima, ali i da uporabni jezik pokazuje veliku polisemičnost te bi ga se metaforički moglo predočiti kao bojno heterogeno identitetsko polje prije negoli rodno. 


\section{3. Želje i mogućnosti mocijske tvorbe}

Kada se od imenica jednog roda izvode imenice drugoga roda s razlikom u spolu, tada se govori o mocijskoj tvorbi čiji su rezultat parne imenice, parnjaci ili nomina mota ${ }^{3}$. Već su duže vremena posebno aktualni ženski parnjaci za zanimanja i zvanja. Veći je dio javnosti danas senzibiliziran i prihvaća njihovu proširenost u uporabi, bilježi se to i u normativno-savjetničkoj literaturi. Tako se u Hrvatskom jezičnom savjetniku razgraničuju situacije ,kad se upotrebljava samo muški parnjak kao semantički neutralan (dvospolan), a kad ženski kao semantički obilježen, koje su situacije referencijalne, a koje nereferencijalne" (Barić, Hudeček, Koharović, Lončarić, Lukenda, Mamić, Mihaljević, Šarić, Švaćko, Vukojević, Zečević, Žagar 1999: 88). Sve je manje onih koji dvoje o smislu takvih tvorbi i koji drže da oni samo unose zbrku u jezik. Prije stotinjak godina to je bilo općeprošireno shvaćanje, nije se vodilo računa o ravnopravnosti te pridonosi li uporaba ženskih mocijskih parnjaka većoj obavijesnosti. Tako se Luka Zore protivi obliku ‘članica' jer je ,član zamjenično ime za muško i žensko; za to nije potreba za žensko kazati članica, nego n.p. Gospogja N.N. je član našega društva" (Zore 1907: 205). U spomenutom primjeru riječ je o konkretnoj situaciji te bi se danas u većini slučajeva posegnulo za ženskim mocijskim parnjakom 'članica'.

Nasuprot tomu ostalo je u jeziku mnoštvo potvrda koje su okamenile muške stereotipe o ženskim poslovima i mušku dominaciju u društvu ${ }^{4}$. Dokaz su tomu imenice s mocijskim sufiksima, ali bez muških parnjaka jer su se njima označivale žene koje su obavljale one poslove koji su povijesno pripadali samo ženama, poput imenica 'dadilja' i 'kućanica' (cf. Kuna, Varga 2009: 185). Povijesno-tradicijski su uvjetovane i ,neparne” imenice 'babica' i 'primalja'. Stjepko Težak za prvu kaže da je etnološki pojam i dijalektno obojena, dok bi 'primalja' mogla vrijediti i u današnjim okolnostima, no zbog činjenice da se njome ne mogu imenovati muške osobe koje obavljaju isti, ona „mora ostati u krugu stilskih obilježenih: povijesnih, razgovornih i nemedicinskih naziva, prepuštajući mjesto (liječniku)

${ }^{3}$ Javlja se u razredu imenica za oznaku osoba i životinja.

${ }^{4}$ Naravno, zbog bioloških razloga ostale su u jeziku neparne imenice: 'dojilja' i 'rodilja', a zbog tvorbenih razloga svoj par nemaju imenice na -ič: 'gonič', 'ribič', 'vodič' ili neke na -ac: 'tvorac', 'kosac', 'znalac'. Podrobnije o tome u Barić (1987). 
porodničaru i (liječnici) porodničarki”" (Težak 1999: 217; istaknuli B.K. i D.N.). Tim primjerom jezikoslovac daje smjernice kako bi trebalo prevladati ,otvorena pitanja” mocijske tvorbe, a to znači izabrati ili predlagati one likove od kojih se mogu izvoditi mocijski parnjaci te tako spriječiti nastanak diskriminirajućih ,neparnih” oblika imenica i učvršćivanje predrasuda o rodnim razlikama u društvu.

Samim smanjivanjem nesklada muških i ženskih oblika, odnosno smanjivanjem broja neparnih imenica izvođenjem do tada njihovih nepostojećih parova, bogati se rječnik, ali to ne znači nužno da društvo na planu rodne ravnopravnosti dobiva novu kvalitetu. Značajnije je da se pojavljuje što više osoba na koje će se novi oblici odnositi. Sve do prije tridesetak godina u jezičnoj praksi nije bilo 'pitomica-desetarica', 'pilotica' i 'pilotkinja', ne zato što su te riječi bile neuklopljene u jezični sustav, već zato što nije bilo (dovoljno) žena na koje bi se ta zanimanja odnosila. Eugenija Barić ističe kako se potreba za izvođenjem i uporabom takvih imenica ne pojavljuje slučajno, već „,zato što ih priziva društvena stvarnost” (Barić 1989: 15). Šrenje mocijske tvorbe zbog tvorbene naravi hrvatskoga jezika trajan je proces, no važnije od izbijanja na površinu novih parova kao samo jednog dijela integracije rodne perspektive jesu pomaci u javnom (i privatnom) životu kao odraz svijesti o nužnosti rodne ravnopravnosti tamo gdje je donedavno nije bilo:

Žene u opasnim zanimanjima: Policajke, vojnikinje, zaštitarke, tjelohraniteljice, vatrogaskinje i gorske spašavateljice (Zaštita 2009) ${ }^{6}$.

Imenovanje žena u novim zanimanjima dokaz je i njihova uvođenja u konstrukciju stvarnosti i to zaista ide njima u korist. O nužnosti imenovanja Dale Spender tvrdi: „Naming is the means whereby we attempt to order and structure the chaos and flux of existence which would otherwise be an undifferentiated mass" (Spender 1980: 84). Svojevrsna krajnost u zahtjevima jest nastojanje feminističkih krugova da se ukloni iz uporabe i jezičnih opisa shvaćanje kako je u hrvatskom jeziku muški rod neutralan jer

${ }^{5}$ Novi nazivi za ,ženska” zanimanja koje se tijekom 1984. pojavljuju u tada vrlo popularnoj ženskoj reviji ,Svijet” zagrebačke novinske kuće Vjesnik (Barić 1987: 12).

${ }^{6}<$ http://zastita.info/hr/clanak/2009/11/za-punu-ravnopravnost-i-u-sigurnosnimsluzbama!,109,3605.html>, 12.12.2014. Navedena rečenica predstavlja podnaslov teksta koji je napisala tadašnja pravobraniteljica za ravnopravnost spolova Gordana Lukač Koritnik. 
to potiče neravnopravnost $\mathrm{u}$ jeziku te bi se trebalo uvijek navoditi muške i ženske likove. Prema takvom shvaćanju mnogi primjeri iz svakodnevice bili bi diskriminirajući, poput trenutačnih naziva televizijskih i radijskih emisija Hrvatske radiotelevizije: Svjedoci vremena, Lovci na natprirodno, Eurograđani, Reporteri, Treća dob - emisija za umirovljenike, Veterani mira - emisija za branitelje, Portret umjetnika u drami, Tumači glazbe. Primjeri pokazuju da množinski likovi imenica u muškom rodu funkcioniraju kao neutralni, ravnopravno se odnose na muškarce i žene te bi ustrajavanje na dosljednom navođenju mocijskih parnjaka stvaralo nazive s visokim stupnjem obilježenosti, pa i podsmjeh: Svjedoci i svjedokinje vremena, Lovci i lovkinje na natprirodno, Eurograđani i eurograđanke, Tumači i tumačiteljice glazbe.

\section{Politička (ne)korektnost i mocijska tvorba}

Činjenica da je ,politička korektnost” ušla u razgovorni i znanstveni diskurs, razlog je zašto se to ime opire jasnom i jedinstvenom određenju, pogotovo što postoje dvije oprečne interpretacije toga pojma. U podlozi pozitivnog određenja političke korektnosti svakako se nalazi pojam tolerancije koji podrazumijeva promicanje jednakopravnosti i različitosti u društvu te odbacivanje jednoumlja. Spolsky i Lambert (2009: 454) političku korektnost određuju kao izbjegavanje šovinističkoga i rasističkog jezika te riječi i iskaza koji obilježuju rasne ili religijske skupine te izražavaju predrasude na temelju roda, a političku korektnost uzimaju i kao kriterij za određivanje što je dobar, a što loš jezik. Nasuprot tomu u nekim intelektualnim krugovima taj pojam ima pejorativno značenje jer podrazumijeva autocenzuru te iskrivljen ili „lažan” jezik. Prema Sari Mills u feminističkim shvaćanjima: „Political correctness is characterised as excessive attention to the sensibilities of those who are seen as different from the norm (woman, gays and lesbians, Black people, the disabled)" (Mills 2012: 133). Opravdavanje i kritiziranje političke korektnosti uvijek se ostvaruje u skladu s određenim sustavom vrijednosti te ga nužno prate norme društveno prihvatljivog jezičnog ponašanja i svojevrsnoga javnog nadzora koji ne podrazumijeva nužno zadaću nekog institucionalnoga tijela, već nevidljivog „suda javnosti”. Marginalizacija i obezvrjeđivanje svoj 
odraz ima i u jeziku, no veoma često nije problem u načinu imenovanja, nego u stajalištima koje sudionici javne komunikacije imaju jedni prema drugom i/ili drugima: izgledu i ponašanju ljudi, običajima, svjetonazoru, političkom promišljanju i sl. Stoga se u nastavku komentira pragmatika mocijskih oblika i što je u podlozi izbora jednog ili obaju članova.

Ženski mocijski parnjaci u područja zanimanja, zvanja i titula danas su postali uobičajeni te je sve manje iznimaka. Izvođenje ženskih oblika u konkretnim situacijama, kada se zanimanje ili zvanje odnosi na određenu osobu, moglo bi se dovesti u vezu i s pojmom političke korektnosti jer on u svom afirmativnom, pozitivnom značenju isključuje verbalnu marginalizaciju određenih skupina ili slojeva te podrazumijeva njihovo potvrđivanje u jeziku. Da nekima u hrvatskom političkom životu uopće nije jasan takav zahtjev, potvrda je sljedeći razgovor vođen u zakonodavnom tijelu - Hrvatskom saboru:

SDP-ov Zoran Vinković upitao je potpredsjednicu Jadranku Kosor što joj se dogodilo: „Zar ste preko noći postali demagog i licemjer?” navodeći kako je prije nekoliko mjeseci prijedlog SDP-a da se dužnosnicima plaće smanje za 6 posto nazvala licemjerjem i demagogijom (...).

- Neću odgovoriti istom mjerom jer sam to ponijela iz vlastitog doma, govorim o kućnom odgoju. A upozorit ću vas i na odredbe Zakona o ravnopravnosti spolova, znači na 'demagog' jer ja nisam muškarac ... (Dalje.com, 11.03.2009; istaknuli B.K. i D.N.).

Samo postojanje Zakona o ravnopravnosti spolova ne jamči kvalitativnu promjenu rodnih odnosa, ali je činjenica da u hrvatskom javnom (političkom) diskursu ima „društvenih prepreka” te da se povremeno i dalje promiče rodna hijerarhija moći. Moć jezika nije samo stručno lingvističko pitanje, već ponajprije društveno i političko. Jedno je pitanje isključivanje žena pomoću jezika, a drugo se odnosi na svijest o moći da se odabirom određenih oblika jezika utječe na konstrukciju određenih dijelova stvarnosti. Unatoč tomu što oblici demagoginja i licemjerka zbog mocijskih sufikasa pripadaju rodno osjetljivom jeziku, postavlja se pitanje bi li osoba postala cjenjenija u danom kontekstu da ju se tako imenuje. Bez obzira na rodnu obilježenost te riječi odražavaju negativni stav spram političkih i moralnih uvjerenja osobe na koju se referira. Mocijska je tvorba samo jezični čin, a tek promjena svijesti odražava stupanj iskrenosti ili licemjerja naspram opravdane težnje označivanja i potvrđivanja žene u jeziku. Upravo to pokazuje odgovor spomenutoga saborskog zastupnika nakon što su 
ga dvije zastupnice iz redova tada vladajuće stranke (HDZ, nap. a.) opetovano upozorile zbog kršenja ravnopravnosti spolova:

Nisam uvrijedio gospođu ministricu zato što je žena. Ovo je prije svega politička ocjena koja govori o tome da je ona doista demagog i licemjer (Dalje.com, 11.03.2009).

Marginalizacija i obezvrjeđivanje svoj odraz dobivaju u jeziku, no veoma često nije problem u načinu imenovanja, nego u stajalištima koje pojedinci imaju prema ženama, u navedenom slučaju jedan saborski zastupnik ${ }^{7}$.

Ilustrativno mjesto susreta novog i starog poimanja (ne)ravnopravnosti spolova; primjer oslobađanja društvene dominacije muškarca, ali i njihova potvrđivanja te u konačnici mjesto gdje se brišu ili ponavljaju oblici u kojima se žene diskriminacijski kvalificiraju jesu oglasi i natječaji za posao. U Zakonu o ravnopravnosti spolova iz 2008. godine ${ }^{8}$ izrijekom u IV. poglavlju, članku 13. stoji: „Pri oglašavanju nije dozvoljeno koristiti izričaje koji uzrokuju ili bi mogli uzrokovati diskriminaciju na temelju spola, bračnog i obiteljskog statusa i spolne orijentacije". U većini slučajeva oglašivači, odnosno portali ${ }^{9}$ koji ih objavljuju, pridržavaju se zakonskih odredbi o poštivanju naziva radnih mjesta u muškom i ženskom rodu, a primijećene su sljedeće inačice:

a) navodi se zanimanje s oba mocijska parnjaka ili se navodi muški oblik s dodanim ženskim mocijskim sufiksom:

promotor/promotorica; odgojitelj/odgojiteljica; piercer/piercerica prodavač/ica; voditelj/ica; doktor/ica; profesor/ica; kuhar/ica;

b) navodi se zanimanje u muškom rodu kao neutralno, a u zagradi se stavljaju kratice rodnih oznaka (m/ž) kojima se naglašava ravnopravnost spolova u prijavi na oglas ili natječaj:

referent nabave $(\mathrm{m} / \check{\mathrm{z}})$; diplomirani inženjeri kemijske tehnologije $(\mathrm{m} / \breve{z})$;

${ }^{7}$ Zastupniku Z. Vinkoviću zbog kršenja Zakona o ravnopravnosti spolova tadašnji je predsjednik Sabora L. Bebić izrekao opomenu jer ,,svojim ponašanjem odstupa od općih pravila ponašanja u Saboru" (Dalje.com, 11.3.2009.). Potvrda je to i sazrijevanja društva jer više neprimijećeno i nekažnjeno ne može proći verbalno nepoštivanje ravnopravnosti spolova.

${ }^{8}<\mathrm{http}$ ://narodne-novine.nn.hr/clanci/sluzbeni/2008_07_82_2663.html>, 12.12.2014.

${ }^{9}$ Primjere koji se navode preuzeti su iz dvaju portala koji objavljuju oglase: MojPosao. net i Ri Telefax Burza, i prikupljani su od 2010. godine. 
c) ima i slučajeva kada je na djelu i svojevrsna hiperkorektnost jer se ravnopravnost tautološki, na dva načina ističe: navode se mocijski parnjaci te se u zagradi još stavljaju i kratice rodnih oznaka:

Traži se voditelj/ica marketinga Avenue Malla Osijek (m/ž);

d) obrnuti primjeri od onih u (c) jesu oni kada se uz ženski lik zanimanja stavljaju oznake $(\mathrm{m} / \check{z})$ što je veoma obilježeno u hrvatskom jeziku jer imenice ženskoga roda nisu neutralne. U takvim slučajevima dvojbena je ravnopravnost kandidata koji se mogu javiti, poslodavci zapravo s velikom vjerojatnošću izravno preferiraju u zapošljavanju ženske osobe u takvim oglasima:

kozmetičarka $(\mathrm{m} / \check{\mathrm{z}})$; djelatnica u Beauty centru i studiju za sunčanje $(\mathrm{m} / \check{z})$; čistačica $(\mathrm{m} / \check{\mathrm{z}})$, domaćica turističkog kompleksa, konobarica $(\mathrm{m} / \check{\mathrm{z}})$.

Ima i primjera kada se imenovanje provodi tako da je pitanje spola neutralizirano imenicom „osoba” te se u dodatku opiše mjesto rada: „osoba za rad u kozmetičkom salonu”, a kada se otvore na stranici oglasa pojedinosti u vezi s radnim mjestom nailazi se na otvoreno kršenje zakona o radu i ravnopravnosti spolova jer je na djelu nejednako postupanje s osobama drugog spola:

Kozmetički salon traži djevojku za rad u kozmetičkom salonu. Potrebno je znanje pedikure, manikure, masaže i depilacije.

Unatoč širenju mocijskih sufikasa i dosljednoj provedbi Zakona o ravnopravnosti spolova, iz oglasa nisu nestale predrasude i stereotipi o povezanosti između određenih zanimanja i roda. Žene se najčešće povezuje s društveno manje vrijednim zanimanjima. Umjesto da se takvo stanje pokuša ispraviti, R. Lakoff ističe kako se zanimanja to tipa zamjenjuju s blažim riječi koje pokušavaju premostiti uvredljiv izraz, pa za kućanicu stoji: ,homemaker, household executive, household engineer" (Lakoff 1973: 58). Izbacivanje riječi ili njihova zamjena ljepšim izrazima neće promijeniti zatečenu situaciju. Nažalost, osim kršenja ravnopravnosti spolova, provodi se i diskriminacije na temelju godina i izgleda. Dokaz su tomu sljedeći oglasi: 
Konobaricu, simpatičnu, komunikativnu u radni odnos (ili studenticu) primam za rad u Mini caffeu.

Mlađu i komunikativnu djevojku, ugodne vanjštine s poznavanjem njemačkog i talijanskog jezika, s položenom B kategorijom, za rad na turističkom vlaku, na moru tražim. Smještaj, prijava i hrana osigurani.

Djelatnicu staru do 30 god. u stalni radni odnos prima caffe bar (istaknuli B.K. i D.N.).

Posljednja tri primjera dokaz su da se izravno, bez okolišanja jezično korektno, ali politički nekorektno narušavaju temeljna ljudska prava i slobode, a to je pravo na posao i jednako postupanje. U tekstu tih oglasa razvidno je diskriminacijsko ponašanje i seksizam jer ne samo da se muškarcima uskraćuje pravo na prijavu na posao, već i većina radno sposobnih žena ne dolazi u obzir pri zapošljavanju jer je bar 3 puta više žena koje nisu mlade ili su starije od 30 godina. O ,profesionalnoj” kvalifikaciji u drugom primjeru koja podrazumijeva „ugodnu vanjštinu” ispred sposobnosti i vještine ,poznavanja njemačkog i talijanskog jezika” i „položene B kategorije” suvišno je raspravljati jer uz sve do sada nabrojene koji su isključeni iz prijave na oglas, trebale bi još odustati i djevojke koje nemaju zamišljene atribute vanjskoga izgleda, zatim one koje imaju „ugodnu vanjštinu”, ali nisu „očekivano” mlade; zatim mlade žene koje su „ugodne vanjštine”, ali su udane. Naravno, sve te spekulacije nisu u području jezikoslovlja, već procjene organa izvršne vlasti o poštivanju radnog zakonodavstva.

Što je značenje manje eksplicitno, to je više odgovornosti na slušatelju pri interpetaciji onog što on konstruira. No činjenica jest kako uporaba mocijskih oblika u navedenim situacijskim kontekstima ne može umanjiti štetu koju čini izbor neprimjerenih izraza koji artikuliraju seksističke koncepte i vrijeđaju ljudsko dostojanstvo jer ograničuju prava i javno odvajaju ljude na osnovi spola, dobi, izgleda i bračnoga stanja. Slaba je dobit za hrvatski jezik što poslodavac rabi naziv 'djelatnica', umjesto nekadašnje 'radnice' ili *‘djelatnika žene', ali je velika šteta nastala u društvu takvim i sličnim tekstovima koji osporavaju jednakost i ravnopravnost svih građana i koji promiču stereotipe o muškim i ženskim zanimanjima te potiču diskriminaciju pri zapošljavanju. 


\section{Zaključno}

Seksistički oblici, muška dominacija u jeziku, otpor rodnoj neravnopravnosti i moguće promjene u jeziku koje bi umanjile rodni nesklad, odnosno ženin marginalizirani položaj u društvu u žarištu su ovoga rada. Nepovoljan položaj žene u evoluciji društva odrazio se i na njezin položaj u jeziku. No to nije razlog da takvo stanje bude učvršćeno i nepromijenjeno. Prije svega veoma je bitno širiti svijest da moć izbora određenih jezičnih sredstava utječe na konstrukciju određene slike stvarnosti. Moć jezika predmet je jezikoslovnih istraživanja, ali je istodobno ona društveno i političko pitanje. Svrha uvođenja rodne perspektive u javnu komunikaciju jest učiniti ženu vidljiv(ij)om u jeziku i ravnopravnom u svakodnevnom životu. Osim toga zadaća je društva na svim razinama jačati svijest o jednakosti i ravnopravnosti svih građana, širiti spoznaje i upozoravati na prikladno (politički korektno) i neprikladno imenovanje zanimanja, zvanja, dužnosti i titula osoba bez obzira na spol te na načine njihove devijacije u različitim kontekstima.

U radu smo uz ostalo pokušali provjeriti koliko se suvremena stvarnost, u kojoj se promiče ravnopravnost, odrazila na leksikografske i jezičnonormativne odredbe rodno osjetljivih oblika, pokazalo se da iz njih još uvijek nije potisnuto patrijahalno shvaćanje i muška slika svijeta te da takve odredbe odražavaju samo nominalnu ravnopravnost. Na planu mocijske tvorbe učinjeni su veliki pomaci u hrvatskom jeziku u odnosu na stanje prije stotinjak godina jer su u konkretnim situacijama uz ženska imena sve rjeđi muški likovi za zanimanja i zvanja: *'premijer’ Jadranka Kosor. Upozorili smo i na slučajeve „inovacija”, posebice u oglasima za posao gdje se ženski lik ističe kao neutralan te se dodatnim oznakama naglašava tobožnja rodna ravnopravnost: „Traži se 'djelatnica' u studiju za sunčanje" (m/ž) čime se implicira da će posao dobiti ženska osoba. Posebno su nazadni primjeri koji odražavaju i promiču predrasude o povezanosti zanimanja i roda jer se uz određena zanimanja daje isključivo prednost ženama „po mogućnosti mlađim djevojkama, a može i studenticama” koje se kvalificira na neprikladan, politički nekorektan način i tako krše zakoni o ravnopravnosti spolova i radnim odnosima. Društvo mora jamčiti primjenu rodno osjetljivog jezika jer i to pridonosi slabljenju i dekonstrukciji predrasuda i stereotipa o rodnim ulogama koji bez potpore govornika neće opstati u jeziku, no bez promjene socijalnog i političkog okvira te 
osvješćivanja članova zajednice diskriminatorna uporaba jezika koja podržava seksističke koncepte neće nestati.

Ni jedan dio jezika kao apstraktnog sustava nije unaprijed određen kao prikladan, rodno osjetljiv niti je određen kao seksistički. Situacijski kontekst jest onaj okvir u kojem se jezik pokazuje kao oblik djelovanja pa uz ostalo on može odražavati, snažiti i razbijati nazadna shvaćanja o rodnim ulogama. Jezik je, stoga, s jedne strane kontekstualan i na njega djeluju promjene u društvu koje teže toleranciji i ravnopravnosti, a s druge strane upozorovanjem na diskriminacijske oblike i davanjem mogućnosti njihove zamjene ubrzavaju se društvene promjene te se pokazuju uspješni načini prevladavanja diskriminacije.

\section{Literatura}

Barić E., 1987, Mocijski parnjaci i njihova upotreba, „Rasprave Zavoda za jezik” sv. 13, str. 9-18.

Barić E., 1989, Ženski mocijski parnjak kao funkcionalna komunikacijska kategorija, „Jezik” br. 37, sv. 1, str. 12-21.

Barić E., Hudeček L., Koharović N., Lončarić M., Lukenda M., Mamić M., Mihaljević M., Šarić L., Švaćko V., Vukojević L., Zečević V., Žagar M., 1999, Hrvatski jezični savjetnik, Zagreb.

Bertoša M., 2001, Jezične promjene i feministička kritika jezika, „Revija za sociologiju" br. 32, sv. 1-2, str. 63-75.

Borić R., 2004, Nejednakost u jeziku. Više od stereotipa, u: Uostalom, diskriminaciju treba dokinuti!: priručnik za analizu rodnih stereotipa, ur. V. Barada, Ž. Jelavić, Zagreb, str. 17-30.

Bratanić M., 2005, Mjesto žene u jeziku, u: Jezik u društvenoj interakciji, ur. D. Stolac, N. Ivanetić, B. Pritchard, Zagreb-Rijeka, str. 37-46.

Cameron D., 1992, Feminism and linguistic theory, Hampshire-New York.

Cesar S., Gospočić A., Ćorić G., Ivanković Knežević K., Obradović-Dragišić G., Tomić-Koludrović I., 2005, Rodna perspektiva u politici i praksi, ur. G. Obradović-Dragišić, Zagreb.

Goffman E., 1977, The Arrangement between the Sexes, „Theory on Society” br. 5, sv. 2, str. 310-331.

Ivić S., 2009, Saborske uvrede, prijetnje, seksizam i opomene, <http://dalje.com/hrhrvatska/saborske-uvrede-prijetnje-seksizam-i-opomene/241818>, 8.01.2015.

Kordić S., 2001, Izražavanje neodređenosti pomoću riječi čovjek, u: Zbornik radova: Drugi hrvatski slavistički kongres, ur. D. Sesar, I. Vidović Bolt, Zagreb, str. 467-477 . 
Kuna D., Varga M., 2009, Rodna osjetljivost u hrvatskom i engleskom jeziku, „Strani jezici" br. 2, str. 179-188.

Lakoff R., 1973, Language and Woman's Place, u: „Language in Society” Vol. 2, No. 1, str. $45-80$.

Mills S., 2012, Gender Matters. Feminist Linguistic Analysis, London.

Penelope J., 1990, Speaking Freely: unlearning the lies of the fathers' tongues, New York-London.

Spender D., 1980, Man Made Language, London.

Sperber D., Wilson D., 2005, Pragmatics, u: Oxford Handbook of Contemporary Philosophy, ed. F. Jackson, M. Smith, Oxford, str. 468-501.

Spolsky B., Lambert R.D., 2009, Language Planing and Policy. Models, u: Concise Encyclopedia of Pragmatics, ed. J.L. Mey, Oxford, str. 452-466.

Škiljan D., 2000, Javni jezik, Zagreb.

Tafra B., 2005, Od riječi do rječnika, Zagreb.

Težak S., 1999, Hrvatski naš (ne)zaboravljeni, Zagreb.

Yule G., 1996, Pragmatics, Oxford.

Znika M., 1994, Gramatički podaci u jednojezičnom rječniku, „Filologija” knj. 22-23, str. 313-322.

Zore L., 1907, Paljetkovanje po oblasti našega jezika, Rad JAZU knj. 170, Zagreb.

\section{Indeks online izvora}

Dalje.com $-<$ http://dalje.com/hr-hrvatska/saborske-uvrede-prijetnje-seksizam-i-opomene $/ 241818>, 11.03 .2009$.

MojPosao.net $-<$ http://www.moj-posao.net/>.

Ri Telefax Burza $-<$ http://burza.com.hr/>.

Zakon o ravnopravnosti spolova, $2008-<\mathrm{http} / /$ narodne-novine.nn.hr/clanci/sluzbeni/2008_07_82_2663.html>, 12.12.2014.

Zaštita - Koritnik G.L., 2009, Za punu ravnopravnost $i$ u sigurnosnim službama!, „Zaštita - časopis za zaštitu i sigurnost osoba i imovina" br. $7-<$ http://zastita.info/ $\mathrm{hr} /$ clanak/2009/11/za-punu-ravnopravnost-i-u-sigurnosnim-sluzbama!,109,3605. $\mathrm{html}>, 12.12 .2014$.

24-sata $-<$ http://www.24sata.hr>, 23.05.2013.

\section{Riječnici}

Anić V., 1991, Rječnik hrvatskoga jezika, Zagreb.

RHISJ - Rječnik hrvatskoga ili srpskoga jezika, 1884-1886, ur. Đ. Daničić, P. Budmani, M. Kračmanov Valjavac, Zagreb.

RHJ - Rječnik hrvatskoga jezika, 2000, ur. J. Šonje. 